\title{
Evaluation of Farming System Research (FSR) on Small Livestock in West Timor of East NusaTenggara
}

\author{
Fuah, A.M1, J. Petheram ${ }^{2}$ and R.Priyanto ${ }^{1}$ \\ ${ }^{1)}$ Department of Animal Production and Technology, Faculty of Animal Science Bogor Agriculture University Jl. \\ Agatis, Kampus IPB Dramaga, Bogor 16680, Indonesia \\ ${ }^{2)}$ Department of Agriculture, Longerenong Agricultual College Victoria \\ Correspondence author : asnath_95@yahoo.com
}

\begin{abstract}
Small livestock complement other parts of the agricultural system in West Timor of East Nusa Tenggara (NTT), since crop residues, weeds and household wastes areavailable feed resources with low cost. The main roles are as farmers' income and consumption, provide liquidity, have high value for ceremonies and cultural functions and are a store of wealth and family security. Pigs, goats and native chickens are comparatively important, with relatively large population. There is little published information on the farming systems in which they are kept, on their role, productivity, limitations or potential. Farming systems research (FSR) has been recognized by many government and international development agenciesas an appropriate approach in agricultural research and development, and the concept has been accepted by some organizations in Eastern Indonesia. However, there are few research programs in which an FSR procedure was followed, and evaluated for their effectiveness, especially in the context of livestock research and development. Evaluation of small livestock farming system research in West Timor, indicates that limitation in times and sufficient data at early stage, as well as broad information of target areas and farmers active involvement, became the main constraints in selecting appropriate location and sites for study purposes. The results of the general evaluation of one year research project suggested that FSR approach was appropriate, even for such a very small scale program. The level of progress achieved was largely dependent on the degree of institutional support provided by regional institutions. There was also need for having better understanding of FSR philosophy and methods for those involved in livestock research and development. Sucess of FSR depends largely on the degree and level of participation of farmers, research workers, and relevant specialists, including comittment of research workers, with close involvement with farmers, their families and problems.
\end{abstract}

Key words: FSR, system approach, evaluation, small livestock

\section{INTRODUCTION}

In the tropical semi-arid environments of East Nusa Tenggara (NTT), the main characteristics including harsh environment, the existence of large areas of nonarable land, (Aldrick, 1987), critical and unutilised dry areas, low availability and low quality of pastures during dry seasons needs global farming system approach (Dixon, J., A. Gulliver, D. Gibbon. 2001). Grazing animals are an important part of the farming systems in the area. For instance, in Sumba and West Timor, ruminant animals such as cattle, buffalo, sheep and goats are traditionally grazed largely on native vegetation until they are required for sale or slaughter for domestic use. Cropping patterns may have little influence on management in the case of certain farming systems in NTT. Monogastric animals such as scavenging pigs and poultry as reported by Kingston, (1985), and Fuah and Priyanto, (2011) were different in this regard, from ruminants. In NTT, they were raised close to the household, where the main feed was determined by the types of staple food consumed by farmers, as is the case in other regions of Indonesia.Small livestock (goats, pigs and chicken) have become increasingly important for local population (NTT Statistics, 2012), and their role is particularly vital amongst the resource-poor farmers who represent the majority of the population in NTT. A rapidly increasing demand for animal products from the growing human population and also a rising consumption of protein, especially by people in the cities became a driving factor to improve animal production. The contribution of small livestock to the national population is quite significant (goats 1,72\%; pigs 0,43\%; chicken 93,38\%. (Livestock Statistic, 2013). However, their economic values were probably understated because only common saleableproducts such as meat and eggs are recorded including sale of live animals.

Small livestock complement other parts of the agricultural system, as secondary component of farming systems. In line with the conventional role of small animals and increases in national economic status, the demand for meat, milk and eggs increases; meat 4,69; eggs 2,82; milk 1,22/capita/year, (Livestock Statistic, 2013). Disparity between supply and demand for animal products become an important issue in order to initiate and improve small livestock productionin Eastern regions of Indonesia.The 
data on livestock provide an even more striking indication of the role of small animals. Native chickens in NTT are more important, because the layer and broiler industries are poorly developed in NTT compared to Indonesia as a whole. Despite the large numbers of small livestock in the villages of West Timor, there is still few published information on the farming systems in which they are kept, their role, productivity, limitations or potential. Most studies conducted on livestock farming (Liem et al., 1993; Marawali et al., 1990; Petheram and Liem, 1990; Simpson, 1990; Dixon et al., 2001) were related to large animals. In general, most studies by researchers in West Timorhad been on testing technology for large animals on research stations (Bamualim et al., 1989; Bamualimet al., 1993; Wirdahayati and KaliTaek, 1993). The few reports on small livestock farming are very general and limited in the information that they provide (Kedang et al., 1987; Gatenby, 1988; Kana Hau, 1993). Some village-bases livestock studies have been carried out(Lopez, et al., 2007), but the results are not comprehensively reported. Farming systems research (FSR) has been recognized by many government and international development agencies (e.g., Surjatna et al., 1982; ILCA, 1983; CIMMYT, 1982; ICRAF, 1983; ICRISAT, 1983; IRRI, 1986) as an appropriate approach to tackling agricultural research and development. While the concept of FSR has been accepted by some organizations in Eastern Indonesia, there are few research programs which followed a recognized FSR procedure, and which have been evaluated for their effectiveness, in the context of livestock research and development. A farming system research need a reflexity of researchers, and appropriate methods and tools for evaluation toward sustainability (Ika et al., 2012; Lopezet al., 2007; Packhamet.al., 2007). Environmental and socio-economic factors became important in farming system research and development (Crimp et al., 2007; Augistine et al.,. 2007), since they significantly contributed to the success.

This study was set out to initiate a small FSR program oriented toward small livestock in particular, and to evaluate the effectiveness of such approach. It was focussed on small livestock rearing in West Timor, by involving a broad evaluation ofsmall farming systems research (FSR) program as an approach to livestock research and development in the region. The framework to be adopted in evaluating the FSR program as an appropriate approach for research and development on small livestock was outlined. Firstly, the results of 14 months research and off-farm experimental study are considered in terms of progress in achieving each stage of the standard FSR procedure. Secondly, the operation of the small FSR program is examined in relation to the ten criteria (mainly from Merrill-Sands et al., 1991), with respect to the institutional setting in which the research was conducted. The aim was to conduct and document an evaluation of the FSR program of the study, for the use by related institution and policy makers in developing appropriate programs for small farmers. The results obtained from the overall study covered Small Farming System Research Program which was oriented towards small livestock development, and its effectiveness and limitations, as a means of livestock research and development in West Timor". The term "small livestock" includes three species; goats, pigs and native chickens, whichare very important to resource-poor farmers of West Timor. Although no formal hypothesis was adopted, the main approach used was a standard FSR approach (adapted from FSR programs in other countries i.e., Packhamet.al., 2007), as an appropriate approach for research and development of small livestock farming in the region. The appropriateness of the program was assessed in general terms of progress achieved through the various stages ofFSR procedure which producing relevant results to farmers). Problemsand limitations experienced during the research period were identified, and the suitability of the institutional context of the research was evaluated.

\section{GENERAL PROCEDURES FOLLOWED IN FSR STUDY OF SMALL LIVESTOCK PRODUCTION}

Approach and Research Procedure Adopted The schedule of activities used in the FSR program was highlighted, and the timing of the various stages of activities of the FSR procedure was following the general criteria of Prtheram (1986). Because of the limited time available for village research, the FSR procedure for the whole study was condensed into a 14 month period, and certain standard FSR activities were not undertaken (e.g., farm trials were only briefly initiated and transfer of results to policy makers and extension was not completed).

The general approach adopted in this study was farming systems research -a soft system approach that has been described and utilized by research organizations in numerous countries (Surjatna et al., 1982; CIMMYT, 1982; Dillon and Anderson, 1984; ILCA, 1983; IRRI, 1986). Although the timing and resources for this study did not allow completion of all components of a standard FSR approach, the research activities conducted all comprise important stages of a procedure which has been well established in various other FSR programs (Zandstra et al., 1981; Lagerman, 1982; Shaner et al., 1982; Patheram, 1986; Collinson, 1987; Sumanto, 1989; Packham et al., 2007).The research procedure adopted in this study is summarized in Table 1. Clarification of objectives

As a first stage of the FSR procedure (Petheram, 1986) indicated that it was necessary to clarify and define the more specific aims of the livestock-oriented FSR Program early at the beginning of research planning. The specific objectives of FSR were: 1) To initiate a small program of FSR, in the Kupang District of West Timor, aimed at improving the benefits to small farmers from rearing small livestock (goats, pigs, chickens); 2) To follow a standard FSR procedure (Pethweam, 1989), within various indicated limitations of time and resources available; 3) To select threerepresentative research sites of different farming systemsin the Kupang District of West Timor; 4) To collect data of the selected sites, in relation to the husbandry and productivity of "small livestock"; 5) To Identify constraints and opportunities in improving benefits to farmers who are rearing small livestock at the sites; 6) To initiate trials for testing ideas in order to improving the performance/ benefits of small livestock to the village farmers.

\section{Collection of data on West Timor}

The main objective of collecting base-data was to gather sufficient information on the region of West Timor to 
facilitate the selection of research sites and the next step of the FSR procedure. Base-data collection involved sourcing and gathering secondary data e.g., on human population, education, land, agro-climate, agriculture and livestock. Because the overall aims of this study fell under one of the institutional and regional aims (Momuat, 1987), some secondary data were readily available from those sources (land classification, maps and statistics; NTASP, 1987). Examination and simplification of these data was carried out give a clear picture of variation in climate, soil types, agriculture and livestock rearing. However, analysis of base data alone was not enough for the level of stratification needed for site selection. Discussions with the project leader of research institution (Nusa Tenggara Australian Support Project), individual interviews with key-persons in the target region, and visits to some villages of the region were required. It transpired that the existing classifications of land were designed mainly for the selection of priority sites for studying crop farming, and were not necessary related to livestock systems. Additional information was collected on the role of small livestock in farming on the various main land user types. The base-data included both secondary and primary data, collected by informal discussions with farmers and officials in the livestock industry.

\section{Selection of Research Sites.}

The main purpose in selection of sites was to choose representative sites for the purpose of the study on the existing farming systems, with a view to designing proposals for improvement of production and benefits for farmers from rearing small livestock.The approach used was to develop a set of criteria on which research sites could be selected, based on the advice of experts in rural development (NTSAP) and livestock research. These criteria were then applied in the selection of village sites from a range numbers of villages in the Kupang District. Villages were considered as suitable unit for research, as there were the units on which much existing data had been collected. Villages also had a well structured administration, with which the FSR project could seek collaboration. Farmers as respondents as well as the target beneficiaries would then be directly and actively involved in this study who would from the early stage, to improve their sense of belonging and to provide accurate infromation needed.

The criteria used in the selection process were:

a) Three (village) sites to be selected for research;

b) Sites to represent different agro-ecological zones (rainfall and soil) and hence land-use types (e.g., rice filed, mixed cropping ) (Aldrick, 1987);

c) Small livestock to be an important component of farming

d) High importance of sites to regional research institutions

e) Accessibility to the research centers

f) Good cooperation of officials, policy makers and farmers for future FRSD

g) Availability of previous socio-economic data;

Some of the above criteria received higher weighting than would have been the case in a long term FSR program. For example, access to sites and political support from the local research institutions were critical requirements for the completion of the research project in the period available.Criterion (d) was therefore considered first, matching the specialinterest to local institutions, village sites were then chosen to represent important land-use types in the Kupang area, taking into account the other criteria.

\section{Description of Research Sites}

The aim of this stages of FSR was to describe the agro-economic characteristics of the sites studies as accurately and effectively as possible (Canali and Segre, 2007). The site description was also intended to provide sound information for use with specialists and other who become involved in diagnosis of problems and defining opportunities of farmers rearing small livestock in the selected sites. The main methods used to develop agro-economic profiles of the selected sites were informal surveys of farmers and time-series monitoring of small livestock enterprises. Rapid appraisal techniques such as visiting target sites, talking to village key persons, interview farmers and their wives, and analyzing previous data were also employed. Although the common approach used in FSR is to avoid time consuming methods (Caruthers and Chambers, 1981), there were reasons for using some conventional methods (surveys and time-series monitoring) in this descriptive phase. First was the accurate estimates of animal productivity could not be obtained by rapid RRA methods. Secondly, farmers were unable to recall dates related to the productive and reproductive events of small livestock. Thirdly, the extensive involvement of farmers in the monitoring study greatly strengthens understanding of farmers real problems by researchers (Rhoades and Booth, 1982; Ashby, 1986), who should thus be better able to diagnose and find solutions to farmer problems.

\section{Farm surveys}

One year long study of village small livestock rearingwas conducted commenced with a relatively formal survey. One hundred and twenty farmers $(30-40 \%$ of rearers in the villages obtained from the village office) were chosen randomly within the three locations, in numbers proportional to total numbers at each site. This gave 42 farmers from Naibonat, 31 from Camplong 1 and 47 from Camplong 2. Eighty eight percent of respondents surveyed reared pigs, seventy three percent reared chickens and sixty six percent reared goats. All farmers selected owned goats or pigs or chickens, or combinations of the species. They were interviewed, based on written questionnaires, which focused on the husbandry of their small livestock. Direct observations on the numbers and condition of the animals and their housing were also made and live weights were measured. The survey procedure followed the following steps: 1) Preparation and pretesting draft questionnaire amongstfarmersample;2)Modification of draft questionnaire to produce final questionnaire; 3) Random selectionof120 farmers from a list of livestock rearers from the 3 villages; 4) Training of field assistants in interview techniques; 5) Conducted farmer interview (approximately 30-45 minutes/ farmer); 7) Livestock observations (10-20 minutes/farmer). The questionnaire sought general information about the farmer's family, the land useand the livestock held and more specifics and detailed information about their holdings of goats, pigs and chickens. The interview was made possible 
according to the available times of farmers. Much of the valuable information was obtained in informal discussions, while weighing and observing animals, because farmers appeared to be worried about formal questions. The progress of research through the standard FSR procedure is summarized in Table1, and each stage of research is Table 1. General Procedures in FSR Study of Small Livestock Production in West Timor

\begin{tabular}{lll}
\hline Research activity & Progress/achievement & Problems/deficiencies \\
\hline Clarification of & Meetings with institute leaders, led to clear (but & Some of the aims set were more like a strategy \\
objectives & $\begin{array}{l}\text { general) aims at an early stage. Farmer acceptance for research, including site selection and } \\
\text { of these aims was then sought with key farmers in suggestion from research institution } \\
\text { the area }\end{array}$
\end{tabular}

Collection of base General statistics on Kupang District and NTT data of region were obtained. More detailed reports on farming systems were obtained from NTSAP. The research step relied heavily on the available secondary data without having more detailed information from other sources

Selection of research sites

Description of research sites (farming systems)

There research sites were selected with a minimum of delay. They represented a considerable range of climate and land-use types, and had high densities of small livestock. Their location in the NTSAP project area was valuable in terms maximizing resources

Sites were described from secondary data (on climateand land-use), rapid appraisal methods (e.g., informal interviews on farming systems). Formal surveys and long-term monitoring described the overall information of small livestock rearing. These results provided useful documentation of existing practices, production levels and problems in the rearing of goats, pigs and native chickens.

Farmer participation in research

Diagnosis of problems

Trials of farms

Trials on stations
Farmer participation increased markedly in the monitoring period (after 6 months). Taking pictures of farmers and small gifts were sometimes necessary to promote interest and trust. Regular and also close contacts, recording of animals and discussion with farmers resulted in a high level of mutual trust-which would be essential if farmers are to be involved in farm trials in the future.

A number of constraints were identified for goat, pig and chicken rearing, under environmental, biological, management and socialcategories. Although some technical solution were applied, most of the opportunities listed for improvement required some forms of support from government. This diagnosis will be valuable indealings with policy makers and extension agencies.

No time was available for developing an extensive program of farm trials. On farmer request, some animals were given veterinary treatment in a form of action research and the results observed. Farmer response to ND vaccination was positive and warrants further support and work to help improve productivity.

A fairly major input was made into feeding trials of supplements for goats, pigs, and chickens. These yielded some useful information for future use in farm trials. Palm pith could replace maize in the diets of chickens and pigs, if materials and protein are balanced.
It would have been valuable to have more detailed information on the region - e.g., so that the selection of research sites could be better justified, and extrapolation of results more valid

If more time was available, sites could have been selected more objectively from regional data, and included more remote villages. Additional research sites are needed in future FSR

More efficient, RRA methods of data collection could be used in future, based on experience gained, e.g., group interviews could have been used to gather some types of information, instead of formal surveys and monitoring, which were expensive. Slight bias foundin the monitoring exercise towards the inclusion of more affluent farmers.

The FSR philosophy said that farmer participation is important at all stages, from site selection, site description, definition of constraints,design of solutions, and trials. Innovative methods were needed to promote fuller farmer participation at the early stages, e.g., use of videos, farmer meetings, group interviews, early trials and demonstration on farms.

More extensive discussions with farmers, social scientists and other specialists (crop scientists), would have been valuable in defining problems and generating ideas for improving the benefits of rearing animals. Group discussion in informal ways would help to identify root problems which limiting the livestock farming.

Usually, in FSR, greater emphasis is given to farm trials than was possible in this study. Many "best bet" trials at early stages of FSR help to encourage farmer interest and participation in research. Fermers need proof through direct testing on farms, although the results might bias.

The level of input into station trials in the program could be questioned, since the research conditions were not ideal and most trials would need to be repeated on farms to achieve better results. 
briefly discussed. The site selection process was aided and strongly influenced by the linkages established with the NTSAP, and the decision made to utilize villages that were part of the NTSAP priority area as research sites. This had the advantage of achieving immediate support from local research institutions policy makers for the project, including some essential financial assistance.The three village sites selected represented important land-use types in the Kupang District and also West Timor as a whole (Aldrick, 1987). This enabled useful data to be gathered on how livestock rearing differs across the different land-use types. Standard procedures and methods in FSR are outlined and this information is used later as a basis for the design of a FSR procedure for this study. Ika, Gibbon and Dedieu (2012) suggested that FSR was a multidicipplinary approach in gaining broad information from research site. The methods used for each stage of the FSR procedure in thisstudy, including the Selection of Research Sites, Description of Sites (Farm Survey and Rapid Appraisals methods), and Trials of Possible Improvements. The results of the Farming Systems Research, trials which arose from the village studies are presented, the effectiveness of the FSR program is broadly evaluated,and some strengths and weaknesses are described.

\section{RESULTS AND DISCUSSION}

One possible disadvantage of the sites selected was that they were relatively close to a main road, compared to many other remote villages within the same land-use types in West Timor. However, study at remote locations would have required considerably more resources and time. The sites selected were considered to represent a stage of "development" that was being approached by many villages in theKupang District. A larger study would have allowed more than there sites and a wider distribution of sites in West Timor. The "site selection" stage of FSR, one of those was rice-based farming, was accomplished reasonably and quite efficient, given the time and resources available for the study, and could be fairly well justified in terms of representativeness of land and small livestock densities, land-use types and the integrated pattern of FSR, as suggested by Senthilkumar et al. (2007).

\section{Description of research sites;}

This showed an improved understanding of farmers' existing systems, aims and practices. Published information on the existing farming systems and farmers' aims and practices in rearing small livestock, was extremely limited or non-existent on many topics converted in this study. The results obtained, provided general information on the rearing of goats, pigs, and chickens which was of value to all involved in the planning and conduct of livestock research and development in the Kupang District and in West Timor generally. The detailed data on livestock rearing in the three villages sites, provided evidence that the descriptive stage of FSR was reasonably successful. Many topics remain to be studied further, and some of the data obtained to date warrant further analysis and useful interpretation. One finding was that village averages for each species (e.g., growth rate) was available but too bulky to present herewith. A valuable form of presentation is to graph each farmer's animal liveweight (e.g., all goats) on one graph at any one time, showing source and date (death, sale etc.) of each animal. These graphs provide a picture of each farmer's management systems, including an indication of growth rates, selling strategy and other information, including environmental effects (Crimp et al., 2007) and economic-based production from such multipurpose production systems (Augistine, 2007). The graph can be used to classify farmers into recommendation domains, and future studies can be limited to the most important domains. Some difficulties in analysis and presentation of the large volume of data were experienced and valuable ideas arose for data handling and use in future FSR. The sample of farmers selected for monitoring may have been more affluent than the average in the villages. It was more difficult to gain cooperation from the smaller-scale rearers, and also less efficient of researcher's time when dealing with very small scale livestock rearers. However, it is critical that the sample of farmers studied includes some representative of the more resources-poor-groups. The information from those farmers are also important to give real pictures and existing condition of the groups for whom, special consideration need to be made to improve their well being. It is also useful to collect certain types of data from non-rearers of livestock.

\section{Identification of major constraints and opportunities in rearing livestock;}

The constraints and opportunities identified through the research process are summarized. The list generated provided a valuable basis for designing research and development programs in the region in the future. Thus, this small FSR program was able at least, to start generating ideas, for improving the benefits of farmers from their small livestock enterprises-a major aim of FSR, and a vitale stage of the FSR procedure. For success in FSR\&D, however, there must be transfer of findings to policy makers, and long-term implementation programs, for which, sustainability in farming systems could be achieved, as recommended by Canali, Petheram and Prior (2007) and Lopez et al. (2007). At this stage, the results of the village have not been published or widely discussed with people from many other disciplines. A future need is to involve a more multidisciplinary range of specialists in helping to define constraints, ideas and opportunities for trials, involving cooperated farmers, and by using their livestock

\section{Farmer participation in design and testing of ideas for improvement;}

The involvement of farmers in this FSR program was described. Farmer participation at almost all stages of FSR, particularly inmonitoring livestock performance over the year,also in designing and testing ideas for "improvement", has led to a vastly improved understanding of farmers'existing systems, aims and practices.Farmer participation in a chicken vaccination program for ND and in simple health programs for small livestock during this study, showed the willingness of farmers to become involved, and will provide a basis for fuller involvement of farmers in future research and development programs. This small FSR program has gained a reasonable level of farmers participation in a short period. However, it was a very time consuming activity, as full contact and intensive communication should be made in daily basis to attract 
and improve their awarenes and cooperation. In this regards, Djamen et al., (2007), suggested that applicative approach, involving all integrated aspects with such complicated interactions is required for farm analysis.

\section{Research station trials;}

Trials on research stations were conducted on the topic of supplementary feeding in the three small livestock species-as feeding and nutrition were identified as major constraints to improving rearing. Some of the feeds tested originated from innovative farmers in the villages. The feeding trials represented vast inputs of time, effort and money, and this expenditure could be questioned. In retrospect, the cost of the station trials was probably not justified by the value studies, including trials on farm. However, the information gained on the feeding value of palm pith and Accaciavillosa will be useful in future work.

Involvement of policy makers in discussing results and

\section{needs of farmers;}

In general terms, it may be concluded that the program of FSR conducted (or commenced) here, progressed with reasonable success through the various steps of a standard FSR procedure, up to the stage of starting to define constraints and opportunities for "improvement" of farming systems, including a start on testing ideas on research stations. Although the small size and time scale of the program limited the results of the study at this stage, the FSR approach may be viewed as logical and appropriate, as it involved close collaboration with various institutions, made use of available resources, and made quite substantial recommendation for livestock improvement by policy makers. The final evaluation of the program will be in the way that the results are adopted and used by livestock, development agencies, policy makers, and extention workers to which they improve farmers' benefits from rearing small livestock.

Table 2 Summary evaluation of institutional aspects of the FSR programs

\begin{tabular}{lll}
\hline Criteria & Achievements & Suggestions for future activity \\
\hline Linkages with & Strong links with regional research centers & In future, contact should be made with \\
experiment stations & were established, with its staffs involved in & livestock research stations of DGLS at \\
& $\begin{array}{l}\text { village studies and with students involved in the } \\
\text { feeding trials conducted on that station }\end{array}$ & $\begin{array}{l}\text { Kupang and of local University. For certain } \\
\text { types of research, linkages are needed with } \\
\text { crop science research stations. }\end{array}$
\end{tabular}

Linkages with farmers Contact with farmers increased as the project developed and was strong after 6 months. A marked increase in farmer interest in rearing was observed over the monitoring period

Linkages with discipline and community specialists

Linkages were established with veterinarians and veterinary service personnel

Social science input to research

Formal collaboration arrangements

Institutional recognition of importance of farmer participation at all stages of research

Strong scientific leadership (with creative experimentation)

Clear setting of goalsand priorities
Contact was made with social scientists during the design of data collection methods

Collaboration with local research institutions was formalized at the start, and resulted in generally good cooperation of staff $n$ the research activities

There was implicit recognition by local research institutions of the need for farmer participation at some stages of research

Strong scientific leadership was a feature of working with local research institutions

General aims for project were set at the start, The aims set forthis project were very broad. with leaders of local research institutions which Within the available time,more specific focussed on this priorty activities
There is a need for more formal farmer groups, through which contact and farmer participation can be developed. This needs careful identification, and support or formalization.

There was a definite need for links to be made with crop scientists, forage specialists, as well as economists-and other disciplines, isolation of researchers, was a problem

Stronger input form social scientists was needed, including their involvement in diagnosis

In future FSR, there would be a need to establish some formal agreement with DGLS and other institutions, e.g., crop institute

Some scientists apparently did not consider working with farmers as "research". This misunderstanding hampers linkages with some institutions. There is a need to explain that farmer participation at all stages of FSR is essential and a legitimate research activity There is a need to improve research capacity and management at farm level objectives would have helped researchers to focus attention and used resources more effectively. Priority species and outcomes were not decided 
The second aspect of evaluation of this FSR program is the consideration of the institutional context of the projectin terms of criteria suggested which is in line with Djamen et al. (2007); Packham,Petheram and Prior (2007).The results of this broad analysis are summarized in Table 2, and discussed briefly in the following section.

\section{Institutional linkages;}

Linkages with livestock experiment stations were a central aspect of this FSR project by involving scientistsfrom local research institutioms starting from the planning to the implementation of the research. Collaboration with other commodity specialists, such as cropping systems workers, would have been valuable. Local extension workers were contacted, but there was apparently little incentive for their involvement in this short program. Where further farm trials are conducted in the future, it would be essential to involve extension agencies, and to develop ways of ensuring their interest and commitment to FSR. Link with farmers were an inherent feature of the FSR procedure, from site description, to defining constraints and running trials. In future studies, it would be desirable to form stronger links with existing farmer organisations/groups of interests, and to establish farmer groups for each livestock species. Care would be needed to include the poorer farmers.

\section{Social science input to on-farm research;}

No specialist social; scientists were involved directly in the research program itself although effort was made to cover sociological aspects of livestock rearing in the survey and monitoring studies. It would have been valuable to have ready access to social scientists during the project, especially in interpreting the results of data collected, and diagnosing problems and realistic solutions for farmers. In the SBPT institutional setting (i.e., a purely livestock research institute), special attention needs to be given to accessing suitably skilled social scientists.

\section{Formal collaboration;}

Collaboration with the local research institutions was formalized at the start of the project and consequently cooperation by staff was generally good with these organizations. There were some formal agreements, in terms of financial support, results report and experimental pigs being given to farmers after trials. The establishment of more formal links with farmer groups in villages might help to ensure long-term farmer participation in research and development projects.

\section{Recognition of need for farmer participation;}

Both regional institutions recognized the need for participation by farmers in village research. The strategy adopted, however, was rather "top down" initially and farmers should have been involved more closely with choice of research sites, defining constraints etc. Their participation, could have improved the relevance of the design and the results. Pig trials had gain farmers interestfor which indicated considerable meaning to their value.

\section{Strong scientific leadership;}

In this small program ofFSR, most decision were made by the researcher, usually in consultation with the leader of the local livestock officers. A larger FSR program would need strong scientific leadership and a well defined management structure.

\section{Clear setting of goals and priorities;}

In retrospect, the project would have benefited from clearer understanding of the goals of FSR and of the research program from the start, by all involved. However, as a postgraduate research project with limited resources, there was difficulty in communicating aims and priorities at all levels. Improved access to and understanding of FSR literature would have helped researcher to define clearer goals. Joint training of staff and leader in FSR methods would help to overcome the problem in future.

\section{Programs designed to be relevant to large numbers of} farmers;

The sites selected for research ensured that the results can have relevance to a large number of farmers in the land-use types studied, within the Kupang District and some other parts of West Timor and also NTT. The high importance of small livestock to the majority of the regional population was obvious.

\section{Studies clustered at selected sites;}

A strength of this FSR program was its location close to localresearch institutions and project offices and to the available resources, by sharing information and resources on similar topics of study.

\section{Regular meetings;}

In this small program, there was no opportunity for regular meetings with a large group of scientists and technicians. Such meetings with research workers undertaking similar activities would have been very valuable, since the study was conducted in an isolated remote areas. Support and intensive assistanship were very valuable and essential under such circumstances.

\section{Long-term commitment to FSR;}

This FSR project was necessarily very short-termas compared to others. The eventual outcome and success of the program will depend on the commitment by other local organizations to continue, and to support the research in the long-term future. Farmer enthusiasm for participation would be seriously affected if the FSR activities were not continued in some forms in the research villages.Considering the small scale of the FSR program conducted, it appears to have met a large proportion of the criteria put forward (MerrillSands et al., 1991) for evaluating the institutional aspects of farmer-oriented research programs. This suggests that the FSR approach can be appropriate and effective for even very small scale research programs, as long as there is adequate institutional support available. Some of the deficiencies identified here such as need for social science input, a larger peer support group, and long-term commitment to FSR, could be, in planning and improving FSR programs in the future

\section{CONCLUSION}

A Farming System Research (FSR) approach had special appeal on livestock, since livestock development in long-term would be very dependent on the establishment of active participation by farmers in 
research. The FSR procedure adopted based on a standard and logical procedure used by many FSR program, need to be adapted to suit the small-scale of FSR project. On-farm trials had given greater priority than the trials on research stations, although on-farm trials with livestock are notoriously time-consuming and unproductive in terms of statistically valid results. Progress found through most stages of the FSR procedure with reasonable success, considering its very small scale, limited resources and the time frame of limited times available. Farm testing of ideas for improvement was the major omission of the program at the farm levels. This studyhad met a large proportion of the criteria suggested by researchers for evaluating institutional aspects of FSR programs, and some deficiencies identified were the need for greater multidisciplinary interactions and for a stronger peer support group, with a long term commitment by local research organizations to an FSR approach. Linkages between institutional and specialist organizations need to be developed, and to establish even stronger links with policy makers, so that they can establish clear and well accepted objective for working in the region.

Based on the overall results, FSR approach could be used as an appropriate mean, even for such a very small scale program, in which the progress and level of progress achieved was largely dependent on the degree of institutional support provided by regional institutions. Regular trainings and extension programs in the aspects of philosophy and methods for those involved in livestock research and developmentwas needed for having better understanding of FSR.Since inplementation of FSR is primarily a people oriented approach, its success depends largely on the degree and level of farmers participation, research workers, and relevant specialists. Therefore, commitmentof researchers, asan integral part of farming system,with close involvement with farmers is essential.

\section{REFERENCE}

Augistine J. Udoh. 2007. Economic Productivity of A Multipurpose Production System. An International Symposium on Methodologies on Integrated Analysis on Farm Production Systems. Catania, Sicily, Italy.

Aldrick, J.M. 1987. The Land Resources of Nusa Tenggara: A Preliminary Compilation of Data. ACILPusatPenelitian Tanah, Victoria, Bogor.

Ashby, J.A. and Sperling, L. 1994.Institutionalising Participatory, Client-Driven Research and Technology Development inAgriculture.Agricultural Administration (Research and Extension) Network. Network Paper No. 49. The Overseas DevelopmentAdministration. London, UK

Ashby, J.A. 1986. Methodology for the participation of small farmers in the design of on-farm trials. Agric. Administ. 22: 1-19

Bamualim, A., Nulik, J. and Widarhayati, R.B. 1989. Hasil-hasil penelitian ternak tahun 1987-1989 di NTT dan NTB. Proyek P3NT-Badan Litbang Pertanian, Departemen Pertanian.

Bamualim, A, Kali Taek, J., Nulik, J., Amd Wirdahayati, R.B. 1993. Pengaruh pemberian sulemen daun kedondong hutan (Lannea grandis), turi (Sesbania grandiflora) dan putal (Corypha gebanga) dan daun putak campur urea terhadap pertumbuhan ternak sapi Bali di musim kemarau. In: Publikasi Wilayah kering. Badan Penelitiandan Pengembangan Pertanian, Departemen Pertanian. Proyek Pembangunan Penelitian Pertanian Nusa Tenggara (NTASP), 1(1): 1-6.

Canali, M., A. Segre. 2007. Evaluation Economic Sustainability of Farming System, the Farming System Analysis and Diagnosis (FASAD) a Method for Regional Analyses. An International Symposium on Methodologies on Integrated Analysis on Farm Production Systems. Catania, Sicily, Italy

Caruthers, I. and Chambers, R. 1981.Rapid appraisal for rural development. Agric. Administ. 8:407-422

CIMMT.1982. Project proposal for support of on-farm research in Eastern and Southern Africa. CIMMYT, Nairobi, Kenya

Collinson, M.P. 1987. Farming systems research: Procedures for technology development.Expl. Agric. 23:365-386

Crimp S., D. Gaydon, M. Howden, C. Hall, P. Poulton, R. Nelson. 2007. Managing Farm Level Production and Environmental Outcomes in A Variable and Changing Climate. An International Symposium on Methodologies on Integrated Analysis on Farm Production Systems. Catania, Sicily, Italy.

DGLS. 2013. Statistical Book of Livestock.Ministry of Agriculture,DirectorateGeneral ofLivestockandAnimal Health, Jakarta.

DGLS 1985. Kebijaksanaan operasional pembangunan peternakan dalam Repelita IV.DepartemenPertanian, DirektoratJenderalPeternakan, Jakarta.

Dhillon, J.L. and Anderson, J.r. 1984.Concept and practice of farming systems research. In: Proceedings of conference on Agricultural Research in Africa, Ed. J.V Mertin. ACIAR Canberra, pp. 171-186.

Dixon, J., A. Gulliver, D. Gibbon. 2001. Global Farming Systems Study: Challenges and Priorities to 2030. FAO, VialedelleTermedi Caracalla, Rome, Italy.

Gatenby, r.M. 1998. Goat husbandry in West Timor, Indonesia.Small Rum. Res. 1: 113-121

ICRAF. 1983. Resources for agro-forestry diagnosis and design.Working Paper No, 7, International Council for Research in Agroforestry, Nairobi, Kenya.

ICRISAT. 1983.Farming systems research.A special report; International Crop Research Institute for the Semi Arid tropics, Patancheru, India.

ICRAF. 1983.Rsources for Agro-forestry diagnosis and design. WorkingPaper No. 7. InternationalCouncil for Research in Agro-forestry, Nairobi, Kenya.

Ideris, A. Ibrahim, A.L. ,Fauziah, O. and husein, A. 1987. Field trials of Newcastle Diases food pellet vaccine. In: Newcastle Disease in Poultry. A new Food Pellet Vaccine. Ed. J.W. Copland.ACIAR Monograph 5, pp. 26-28

Ika Darnhofer, D. Gibbon, B. Dedieu. 2012. Farming System Research: An Approach to inquiry. Book Farming Systems into the 21st Century: The new Dynamic.

ILCA. 1983. Annual report, 1983. Humid Zone Programme, International Livestock Centre for Africa, Ibadan, Nigeria.

IRRI. 1986. Farming Systems Socioeconomic research 
Training Course: Training Material, Vol 1 and 2, Agricultural Economic Department, Los Banos, Laguna, Philippines.

Kanahau, D., Marawali, H and Bamualim, A. 1993. Pengaruh supplement putakdanblok mineral padaternak kambing yang digembalakan sianghari. In: Publikasi Wilayah Kering. Badan Penelitian dan pengembangan Pertanian, Departemen Pertanian, NTASP 1(1): 57-61

Kedang, A., Bani, P.N., Saleh, A., dan Liem, C. 1987. Monitoring produksiternak ayam, kambing dan babi yang dipelihara petani di desa Naibonat dan desa Tarus. Laporan hasil Penelitian Tahun 1987/1988. Sub balai Penelitian Ternak Lili, Kupang.

Kingston, D.J. 1985. Small Animals Program, NTT Integrated Development Project. Review, pp. 1-48

Lagerman, J. 1982. Farming system research as a tool for identifying and conducting research and development projects. Agric. Administ. 11: 139-153

Lopez Ridaura S., H. Hengsdijk, H. Kante, M.Lubbers, H. Van Keulen. 2007. Evaluating Alternatives for Sustainble Farming System in the Cercle de Koutiala, Mali. A Multi Scale Approach.An International Symposium on Methodologies on Integrated Analysis on Farm Production Systems. Catania, Sicily, Italy.

Mommuat, E.O. 1987. Makalahpengarahanpada farming systems research training cource, Maros 13-24 Juli 1987. Nusa tenggara Agricultural Support Project (NTASP)

Liem, C., Marawali, H.H., Kanahebi, A., Tonga, U. and Petheram, R.J. 1993. Pengolahan sawah dengan traktor, luku, rencah dan tenaga manusia di desa Tarus, kabupaten Kupang, Nusa Tenggara Timur. In: Publikasi Wilayah Kering. Badan Penelitian dan Pengembangan Pertanian, Departemen Pertanian. Proyek Pembangunan penelitian PertanianNusa Tenggara(NTASP) 1(1):35-41

Marawali, H., Liem, C., Saleh, A., Tonga, U. and Djuma'ih. 1990. The training of farmers to makewooden implements and to train cattle or work: Farm trials in Kupang, West Timor. In: Drought Animal Power Project. Ed. E. teleni.DAP Project Bulletin ACIAR, 10: 18-24

Merril-Sands, D.M., Biggs, S.D., BBingen, R.J., Ewel, P.T., McAllister, J.L. and Poats, V. 1991. Institutional considerations in strengthening on-farm client oriented researchinnationalagriculturalresearchsystems: Lessons from a nine-country study. Expl. Agric. 27: 343-373.

Packham, R., J. Petheram, R. M. Prior. 2007. A Farming System Research (FSR) as a Platform for RD \& $\mathrm{E}$ in Agriculture and NRM. EFS Journal, Vol. 3.

Petheram, R.J. 1986. A Farming Systems Approach to Ruminant Research in Java. $\mathrm{PhD}$ thesis, University pf New England.

Petheram, R.J. and Liem, C 1990.A Greater role for animal traction. In: Drought Animal Power Project. Ed. E. Teleni. DAP Project Bulletin. ACIAR, 10: 1-7

Rhoades, R.E. and Booth, R. 1982. Farmers back to farmers: a model for generating acceptableagricultural technology. Agric. Admin. 11(2): 127-137

Shaner, W.W., Philipp, P.F. and Schemehl, W.R. 1982.Farming Systems Research and Development. West view Press, Boulder, Colorado.

Sumanto. 1989. Farming Systems Research Approach to improving Farmer Benefits From Drought Animal Enterprises

Senthilkumar, K., M. Lubbers, N. De Ridder, P.S. Bindraban, K.E. Giller. 2007. Exploring Alternatives for Rice-based farming System in Tamil Nadu, India. An International Symposium on Methodologies on Integrated Analysis on Farm Production Systems. Catania, Sicily, Italy

Simpson,S. 1990. Tools for farming in the development of Timorese agriculture. In: DraughtAnimal Power Project. Ed.E. Teleni. DAP Project Bulletin. ACIAR, 10: 8-17

Surjatna, E.S. Ismail, I.G. and McIntosh, J.L. 1982.Cropping systems research in Indonesia. Report of a Workshop on Cropping Systems Research in Asia. IRRI, Los Banos, Philippines

Wirdahayati, R.B. and KaliTaek, J. 1993. Pemanfaatan jerami dan kacang tanah sebagai pakan ternak sapi. Ih: Publikasi Wilayah Kering. Badan Penelitian dan Pengembangan Pertanian, Departemen Pertanian. Proyek Pembangunan Penelitian Pertanian Nusa Tenggaran )NTASP), 1(1): 25-28.

Zandstra, H.C., Price, E.C., Litsinger, J.A. and Morris, R.A. 1981. A Methodology for Onfarm Cropping Systems Research.International Rice Research Institute, Manila, Philippines. 